\title{
Analisis indikator keberkahan berzakat bagi muzaki di jalur Joglosemar
}

\author{
Ahmad Mifdlol Muthohar \\ Institut Agama Islam Negeri (LAIN) Salatiga \\ E-mail:mifdlol@gmail.com
}

DOI: $10.18326 /$ ijtihad.v17i2.217-240

The purpose of this study is to find out the concept of blessing in giving zakat according to Islamic teaching and to deepen its indicators felt by muraki. Research method used in this study is qualitative approach. Technique of collecting data is documentation, observation and interview. The interview was conducted twice. The first step was done to 396 respondents, and then it's continued to the second step with 20 different respondents. Sampling technique used in this study is purposive random sampling. Research findings showed that $98 \%$ of muzaki stated that they felt the existence of blessing in giving zakat, and according to them the highest blessing is inner peace; however when high percentage is correlated to the tendency of giving zakat to zakat institution, the result is not correlated. In addition to those mentioned, muzaki felt religious experiences related to blessing after they paid rakat. The highest blessings they felt most are: inner peace, easy of business, calm feeling, effective property, and far from harmful things.

Penelitian ini bertujuan untuk mengetahui konsep keberkahan berzakat dalam ajaran Islam dan mendalami indikator-indikator keberkahan yang dirasakan oleh muzaki dalam berzakat. Metode penelitian menggunakan pendekatan kualitatif. Teknik pengumpulan data dalam penelitian ini adalah dengan dokumentasi, observasi dan wawancara. Wawancara dilaksanakan melalui dua tahap. Tahap pertama dilakukan terhadap 396 responden. Lalu dilanjutkan wawancara secara lebih mendalam pada tahap kedua, dengan responden yang berbeda, sejumlah 20 respoden. Sampel yang digunakan dalam penelitian ini adalah sampel jenis purposive random sampling, Hasil penelitian menunjukkan bahwa $98 \%$ muzaki menyatakan bahwa mereka merasakan adanya keberkahan dalam berzakat dan keberkahan yang paling tinggi menurut mereka adalah ketenangan batin. Akan tetapi ketika persentase tinggi tersebut dikaitkan dengan kecenderungan pilihan berzakat ke lembaga zakat, maka hasilnya tidak berkorelasi. Selain itu, muzaki juga merasakan pengalaman-pengalaman religius yang terkait dengan keberkahan setelah mereka berzakat. Adapun keberkahan yang paling mereka rasakan adalah: ketenangan batin, kemudahan urusan, perasaan tentang keridhaan Allah, efektifitas harta dan terhidar dari hal-hal yang membahayakan.

Keywords: Muzaki; blessing; inner peace 
ljthad: Jurnal Wacana Hukum Islam dan Kemanusiaan, Volume 17, No. 2, Desember 2017: 217-240

\section{Pendahuluan}

Konsep zakat secara sederhana menegaskan bahwa di dalam harta orang kaya terdapat hak orang miskin yang harus ditunaikan (Lihat QS. 9: 60, 103, dan QS. 59: 7). Artinya kewajiban zakat lebih ditekankan untuk upaya pemerataan pendapatan. Pemerataan pendapatan ini dianggap penting oleh al-Qur'an, sehingga muncul dalam al-Qur'an bahwa harta tidak boleh beredar hanya di kalangan orang-orang kaya saja (QS. 59: 7). Dalam rangka pemerataan pendapatan melalui dana zakat, PIRAC (Public Interest Research and Advocacy Center) meneliti di 10 kota besar dan hasilnya didapati bahwa potensi dana zakat di Indonesia mencapai Rp. 9,09 triliun pada tahun 2007 dengan asumsi terdapat 29,065 juta keluarga sejahtera yang membayar zakat rata-rata Rp. 684.550 per tahun per orang (Antara, 12/9/2008).

PIRAC juga mendapati tingkat kesadaran muzaki terhadap kewajiban membayar zakat pun meningkat, dari 49,8\% pada tahun 2004, menjadi 55\% pada tahun 2007. Dari angka kesadaran itu, sebagian besar muzaki kemudian membayarkannya, yakni sebesar 95,5\% dari mereka. Jadi, dari $55 \%$ masyarakat yang sadar akan kewajiban zakatnya, 95,5\% kemudian menunaikannya (Antara, 12/9/2008). Paparan riset PIRAC tersebut, menunjukkan masih adanya sebesar $45 \%$ muslim di Indonesia yang berkewajiban menunaikan zakat, tetapi masih belum menunaikan zakat. Angka 45\% ini cukup besar. Seandainya asumsi potensi dana zakat di Indonesia sebesar Rp. 9,09 triliun, maka 4,3 triliun di antara mereka masih belum sadar akan kewajiban zakatnya.

Hidayat Nurwahid mengatakan bahwa potensi zakat rakyat Indonesia mencapai Rp 17 triliun. Hampir dua kali lipat dibanding penemuan PIRAC. Namun realisasi yang dapat dihimpun hanya sebesar Rp 700 miliar. Dengan demikian masih ada 16,5 triliun yang belum terhimpun (Antara, 12/9/2008). Berikutnya kajian Asian Development Bank (ADB) menyebutkan, bahwa potensi pengumpulan zakat di Indonesia bisa mencapai Rp 100 triliun per tahun (Rama, 2010). Dan bahkan yang terakhir menyebutkan bahwa potensi zakat yang bisa dihimpun di Tanah Air mencapai Rp 217 triliun per tahun, berdasarkan survei yang dilakukan BAZNAS, Institut Pertanian Bogor (IPB) dan Islamic Development Bank (IDB) pada 2011 (Republika, 2011).

Di antara problem tersebut adalah minimnya kesadaran mereka dalam berzakat. Lebih khusus lagi minimnya kesadaran mereka untuk memberikan dana zakat ke lembaga-lembaga zakat. Beberapa penelitian sebelumnya telah banyak menyebutkan tentang faktor-faktor 
yang mempengaruhi seorang muzaki berzakat di lembaga zakat, di antaranya adalah faktor pendapatan, keagamaan, variabel etos kerja, peran pesantren (Syafei, 2003). Ada pula yang menyebutkan bahwa faktor-faktor yang menyebabkan masyarakat tidak berzakat ke Badan Amil Zakat (BAZ) adalah: (1) Faktor psikologi (kekhawatiran zakat mereka tidak sampai); (2) Faktor Sosiologis (tradisi membayarkan zakat secara langsung kepada mustahik); (3) Faktor Transparansi di BAZ; (4) Faktor promosi yang tidak optimal; (5) Faktor Sumber daya manusia, yang mengelola secara khusus terhadap dana-dana zakat (Rosadi, 2007). Sedangkan yang lain menyebutkan bahwa keberkahan adalah salah satu faktor yang memotivasi para pengusaha kayu untuk menunaikan zakatnya (Hervina, 2004).

Faktor keberkahan merupakan faktor yang menjadi dasar pijakan penting dalam penelitian ini. Beberapa pakar ekonomi Islam telah membahas faktor keberkahan dalam aktivitas ekonomi, namun belum merincikan tentang makna keberkahan itu sendiri. Zamir Iqbal dan Abbas Mirakhor misalnya, salah satu pakar ekonomi Islam yang mengingatkan pentingnya faktor motivasi penting dalam sistem Islam, yaitu faktor barakah (baca: berkah) (Iqbal dan Mirakhor, 2007: 42-43). Oleh karena itu, penelitian ini berjudul, "Preferensi Keberkahan dalam Menyalurkan Dana Zakat”.

Rumusan masalah yang dapat diambil dari permasalahan di atas sebagai berikut: 1). Bagaimana konsep berkah dalam mengeluarkan zakat dalam ajaran Islam dan seberapa besar keberkahan yang dirasakan muzaki ketika mereka mengeluarkan kewajiban zakat. 2). Bagaimana para muzaki merasakan indikator-indikator keberkahan dalam menyalurkan dana zakat dalam kehidupan mereka.

Riset ini penting bagi kemaslahatan umat Islam mendatang, karena memiliki tujuantujuan sebagai berikut: 1) Untuk menemukan konsep keberkahan dalam mengeluarkan zakat menurut ajaran Islam dan mengukur tingkat keberkahan yang dirasakan oleh para muzaki ketika mereka berzakat; dan 2) Untuk mendalami indikator-indikator keberkahan dalam menyalurkan dana zakat dalam kehidupan mereka.

Pada ranah akademik, tujuan-tujuan tersebut di atas sesungguhnya merupakan pengembangan teori atau konsep yang sudah ada. Jika sebelumnya beberapa variabel-variabel yang sudah ada digunakan untuk menemukan hubungannya dengan berzakat, maka pada penelitian ini dikembangkan lagi hubungannya dengan berzakat ke lembaga zakat. 
ljtihad: Jurnal Wacana Hukum Islam dan Kemanusiaan, Volume 17, No. 2, Desember 2017: 217-240

Kegunaan penelitian ini secara akademik, akan bermanfaat dan dapat memberikan kontribusi empirik, terutama bagi lembaga-lembaga zakat dan para pengelola atau praktisi zakat secara umum, untuk menentukan langkah-langkah riil yang harus mereka tempuh setelah mengetahui secara tepat tentang karakter personal seputar perasaan berkah muzaki khususnya di ruang lingkup Joglosemar. Selain itu, riset ini akan sangat bermanfaat bagi para ulama, para akademisi dan masyarakat secara umum, agar pengelolaan zakat mendatang lebih tepat guna. Seringkali faktor internal yang terkait dengan muzaki tidak begitu diperhatikan oleh para stakeholder zakat. Padahal ini adalah sesuatu yang penting dan dapat bermanfaat bagi optimalisasi pengelolaan zakat di masa mendatang.

\section{Tinjauan pustaka}

Teori yang digunakan dalam penelitian ini adalah teori motivasi kerja Gomes (2003: 180), yang dipadukan dengan teori Clifford Geertz, tentang motivasi agama (Geertz, 1973: 90). Selain itu, teori fenomenologi juga dipergunakan untuk menjelaskan makna berkah dalam kehidupan masyarakat muslim Indonesia. Teori fenomenologi yang dipergunakan adalah teori Edmund Husserl. Menurut Husserl, pertama yang harus dilakukan adalah menghilangkan dari tindakan kita semua keyakinan yang kita miliki sampai sekarang, termasuk semua pengetahuan kita. Biarkan ide itu menuntun semua meditasi kita pada pertama kalinya menjadi sebuah ide mengenai suatu ilmu yang akan dikukuhkan secara radikal dan murni yang pada akhirnya meliputi semua isi pengetahuan (Husserl, 1966: 49).

Dalam Q.S. al-A'raf [7]: 96 telah dijelaskan bahwa sekiranya penduduk negeri-negeri beriman dan bertakwa, pastilah Allah akan melimpahkan kepada mereka berkah dari langit dan bumi, tetapi mereka mendustakan (ayat-ayat itu), sehingga Allah menyiksa mereka karena pendustaan tersebut.

Demikianlah setiap muslim harus meyakini bahwa tatkala mereka beriman dan bertakwa dengan sesungguhnya, pasti akan mendapatkan keberkahan dari Allah s.w.t. yang muncul dari segala penjuru, baik dari langit maupun dari bumi. Iman dan takwa tersebut tentulah yang sesuai dengan standar yang dibakukan oleh Allah s.w.t dan Rasul-Nya, melalui al-Qur'an

maupun Sunnah Nabi s.a.w. Di antara bukti adanya iman dan takwa dalam diri seorang muslim adalah melaksanakan rukun Islam dan rukun iman. Membayar zakat merupakan 
rukun tersebut, yang dapat mencapai pada keberkahan. Hal ini dinyatakan oleh al-Baidhawi (w. $791 \mathrm{H}$ ) bahwa mengeluarkan zakat akan menarik adanya keberkahan dalam harta dan membuahkan keutamaan jiwa (Al-Baidhawi, 1998 : 291). Demikian pula an-Naisaburi menyebutkan bahwa pengertian zakat secara syar'i adalah kadar harta yang dikeluarkan dari harta yang telah men capai nisab, di mana itu akan menambah keberkahan pada harta tersebut (An-Naisaburi, 1994 : 209).

Zamir Iqbal menyebutkan bahwa salah satu aspek penting dalam menganalisis sebuah sistem ekonomi adalah yang berkaitan dengan struktur motivasi pendorong yang hendak diwujudkan oleh sistem tersebut. Maksud dari aspek motivasi tersebut adalah untuk memastikan apakah seorang individu dalam sistem tersebut akan menjadikan motivasi tersebut sebagai utility-maximizing ketika mengikuti aturan perilaku yang diuraikan oleh sistem tersebut, atau justru sebaliknya. Faktor motivasi penting dalam sistem Islam itu adalah adanya konsep barakah. Konsep barakah ini menegaskan bahwa membelanjakan kekayaan karena Allah tanpa berharap laba secara langsung dari si penerima, itu sebenarnya tidak mengurangi harta, tetapi justru akan mengembangkannya (Iqbal, 2007: 42-43).

Konsep barakah sebagaimana yang dikatakan oleh Iqbal di atas berlaku untuk semua aturan Islam yang harus ditaati oleh setiap muslim. Masyarakat Indonesia lebih akrab dengan istilah "berkah". Di antara aturan yang harus diikuti untuk mendapatkan keberkahan dari Allah s.w.t. adalah yang terkait dengan kewajiban zakat. Pelaksanaan zakat harus diawasi oleh penguasa, dilakukan oleh petugas yang rapi dan dipungut dari orang yang wajib mengeluarkan untuk diberikan kepada yang berhak menerimanya (Abdurrasul, 1980: 175). Dalil bahwa zakat harus dikelola langsung oleh pemerintah adalah Q.S. At-Taubah [9]: 103 sebagai berikut:

"Ambillah zakat dari sebagian harta mereka..." (Q.S. At-Taubah [9]: 103).

Dalam ayat tersebut jelas bahwa perintah Allah s.w.t langsung ditujukan kepada Nabi s.a.w. sebagai penguasa agar memungut harta shadaqah. Jumhur ulama semenjak dahulu sampai sekarang mengatakan bahwa yang dimaksud harta shadaqah dalam ayat tersebut adalah harta zakat (al-Qaradhawi, 1973: 734). Sehingga selain perintah itu ditujukan kepada Nabi s.a.w., juga kepada setiap orang yang mengurus urusan kaum muslimin sesudahnya.

Bahkan khalifah Abu Bakar juga menggunakan ayat ini sebagai dalil, tatkala hendak memerangi orang-orang yang tidak mau membayar zakat sepeninggal Rasul s.a.w. Tidak 
ljtihad: Jurnal Wacana Hukum Islam dan Kemanusiaan, Volume 17, No. 2, Desember 2017: 217-240

terdapat seorang sahabat pun yang mengatakan bahwa ayat tersebut bukan untuk wajib zakat. Demikian pula ulama-ulama Islam sesudah mereka, dalam rangka menolak segala kesyubhatan itu.

Dalam hadis shahih yang diriwayatkan Bukhari, Muslim, Abu Dawud, Tirmidzi, anNasa’i dan Ibnu Majah, dari Ibnu Abbas bahwa Nabi s.a.w. ketika mengutus Muadz ke Yaman, beliau berkata:

Beritahukanlah kepada mereka, bahwa Allah s.w.t. telah mewajibkan dari sebagian hartaharta mereka, untuk disedekahkan. Diambil dari orang kaya untuk diberikan kepada mereka yang fakir. Apabila mereka mentaatimu dalam hal ini, maka peliharalah kehormatan harta mereka dan takutlah doa orang yang teraniaya. Sungguh tidak ada penghalang antara doa mereka itu dengan Allah s.w.t. (HR. 6 Perawi terkemuka, dari Ibnu Abbas).

Hadis ini menjelaskan bahwa urusan zakat itu diambil oleh petugas untuk dibagikan, tidak dikerjakan sendiri oleh orang yang mengeluarkan zakat. Al-'Asqalani menjelaskan bahwa penguasa adalah orang yang bertugas untuk mengumpulkan dan membagikan zakat, baik ia sendiri secara langsung maupun oleh wakilnya yang ditunjuk. Apabila mereka menolak, maka zakat itu akan diambil paksa dari mereka (Al-Asqalani, tt, : 23).

Ulama-ulama kontemporer seperti Abdul Wahab Khalaf dan Muhammad Abu Zahrah, sebagaimana dijelaskan al-Qaradhawi, mengatakan bahwa jika penguasa mengetahui bahwa rakyatnya tidak membayarkan zakat, maka hendaklah mereka mengambilnya secara paksa (Al-Qaradhawi, 1973: 737).

\section{Metode penelitian}

Ruang lingkup penelitian ini adalah jalur Joglosemar (Yogyakarta, Solo/Surakarta, dan Semarang). Dalam Perda Provinsi Jawa Tengah No. 21 Tahun 2003 disebutkan bahwa Kawasan Joglosemar itu meliputi Yogyakarta, Solo dan Semarang dan jalur yang melewati Joglosemar merupakan jalur yang penting dan strategis. Jalur tersebut dilewati 13 kabupaten/ kota, yaitu: Yogyakarta, Klaten, Surakarta (Solo), Sukoharjo, Karanganyar, Boyolali, Salatiga, Kabupaten Semarang, Kota Semarang, Temanggung, Kabupaten Magelang, Kota Magelang dan Sleman. Alasan pemilihan jalur Joglosemar sebagai obyek penelitian, karena jalur ini merupakan jalur bisnis terbesar di wilayah provinsi Jawa Tengah dan Yogyakarta, yang masyarakatnya merupakan masyarakat yang heterogen. 
Penelitian ini menggunakan pendekatan kualitatif. Teknik pengumpulan data dalam penelitian ini adalah dengan dokumentasi, observasi dan wawancara. Dokumentasi merupakan instrumen yang digunakan untuk mengumpulkan data-data dengan menelusuri berbagai jenis kepustakaan. Tujuan dari pengumpulan data tersebut untuk memperoleh teori, konsep, dalil, pandangan para pakar terkait dan juga hasil penelitian terdahulu yang berhubungan dengan materi kajian serta data-data sekunder sebagai langkah pertama penelitian (Supardi, 2005: 61). Observasi adalah instrumen pengumpulan data dengan cara mengamati objek yang diteliti, didukung oleh pengumpulan dan pencatatan data secara sistematis (Nasution, 1996: 10). Dalam penelitian ini observasi dipergunakan sebagai sumber data yang memberikan informasi tambahan tentang hal-hal yang terkait dengan muzaki dan keberkahan yang mereka rasakan. Wawancara merupakan instrumen dalam bentuk tanya-jawab antara peneliti dengan responden untuk memperoleh suatu fakta atau data dengan melakukan komunikasi langsung dengan responden, baik berbicara secara langsung atau menggunakan teknologi komunikasi (Supardi, 2005: 121). Dalam penelitian ini, wawancara dipergunakan untuk memperjelas hal-hal yang belum diisi ataupun belum begitu jelas disebutkan dalam kuesioner. Wawancara dilaksanakan melalui dua tahap. Tahap pertama dilakukan terhadap 396 responden. Lalu dilanjutkan wawancara secara lebih mendalam pada tahap kedua, dengan responden yang berbeda, sejumlah 20 respoden.

Sampel yang digunakan dalam penelitian ini adalah sampel jenis purposive random sampling, yaitu pengambilan sampel yang dalam hal ini peneliti menentukan batas-batas subyek yang dijadikan sebagai sampel penelitian. Adapun batas-batas tersebut sebagai berikut: 1) Responden yang membayar zakat pada lembaga zakat milik pemerintah (BAZ) dan swasta (LAZ); 2) Responden yang membayar zakat pada BAZ/LAZ dan juga kepada mustahik secara langsung; 3) Responden yang membayar zakat kepada mustahik secara langsung; 4) Responden yang membayar zakat kepada amil zakat di masjid atau mushalla; 5) Responden yang membayar zakat kepada lembaga zakat selain BAZ/LAZ dan masjid/mushalla.

Analisis kualitatif dalam penelitian ini melalui tiga tahap: (1) Tahap editing, sebagai persiapan melakukan pengecekan data yang telah terkumpul sekaligus pengecekan keabsahannya, (2) Tahap tabulasi, untuk mengklasifikasikan data yang relevan dan tidak relevan, untuk kemudian diambil hanya data yang relevan dengan penelitian, (3) Tahap analisis, 
ljtihad: Jurnal Wacana Hukum Islam dan Kemanusiaan, Volume 17, No. 2, Desember 2017: 217-240

yang membandingkan, menarik kesimpulan dan membuat kategori baru sesuai dengan tujuan penelitian.

\section{Konsep berkah berzakat menurut ajaran Islam dan persentase keberkahan}

Dalam Q.S. al-A'raf [7]: 96 telah dijelaskan bahwa sekiranya penduduk negeri-negeri beriman dan bertakwa, pastilah Allah akan melimpahkan kepada mereka berkah dari langit dan bumi, tetapi mereka mendustakan (ayat-ayat itu), sehingga Allah menyiksa mereka karena pendustaan tersebut.

Setiap muslim meyakini bahwa tatkala mereka beriman dan bertakwa dengan sesungguhnya, pasti akan mendapatkan keberkahan dari Allah s.w.t. yang muncul dari segala penjuru, baik dari langit maupun dari bumi. Iman dan takwa tersebut yang sesuai dengan standar al-Qur'an dan Sunnah Nabi s.a.w. Sebagaimana dikatakan al-Baidhawi (w. 791 H) bahwa mengeluarkan zakat akan menarik adanya keberkahan dalam harta dan membuahkan keutamaan jiwa (AlBaidhawi, 1998, : 291). Demikian pula an-Naisaburi menyebutkan bahwa pengertian zakat secara syar'i adalah kadar harta yang dikeluarkan dari harta yang telah mencapai nisab, di mana itu akan menambah keberkahan pada harta tersebut (al-Naisaburi, 1994, : 209).

Zamir Iqbal menyebutkan bahwa salah satu aspek penting dalam menganalisis sebuah sistem ekonomi adalah yang berkaitan dengan struktur motivasi pendorong yang hendak diwujudkan oleh sistem tersebut. Maksud dari aspek motivasi tersebut adalah untuk memastikan apakah seorang individu dalam sistem tersebut akan menjadikan motivasi tersebut sebagai utility-maximizing ketika mengikuti aturan perilaku yang diuraikan oleh sistem tersebut, atau justru sebaliknya. Faktor motivasi penting dalam sistem Islam itu adalah adanya konsep barakah. Konsep ini mengacu pada adanya keberkahan yang tidak tampak tetapi bersifat materiil, yang hasilnya dapat diobservasi. Bermula dari perilaku yang memiliki motivasi dan tujuan untuk mencapai keridhaan Allah s.w.t., yang dapat meningkatkan tingkat keuntungan. Konsep barakahini menegaskan bahwa membelanjakan kekayaan karena Allah tanpa berharap laba secara langsung dari si penerima, itu sebenarnya tidak mengurangi harta, tetapi justru akan mengembangkannya (Mirakhor, 2007: 42-43).

Konsep barakah sebagaimana yang dikatakan oleh Iqbal di atas berlaku untuk semua aturan Islam yang harus ditaati oleh setiap muslim. Masyarakat Indonesia lebih akrab dengan 
istilah "berkah". Di antara aturan yang harus diikuti untuk mendapatkan keberkahan dari Allah s.w.t. adalah yang terkait dengan kewajiban zakat. Pelaksanaan zakat harus diawasi oleh penguasa, dilakukan oleh petugas dan dipungut dari orang yang wajib mengeluarkan untuk diberikan kepada yang berhak menerimanya. Hal itu dikarenakan zakat itu sendiri merupakan hak jamaah umat Islam yang dibebankan atas individu-individu muslim, untuk menjamin kecukupan sekelompok umat Islam yang belum tercukupi secara ekonomi (Abdurrasul, 1980: 175).

Dalil bahwa zakat harus dikelola langsung oleh pemerintah adalah Q.S. At-Taubah [9]: 103 sebagai berikut:

Ambillah zakat dari sebagian harta mereka, dengan zakat itu kamu membersihkan dan mensucikan mereka dan berdoalah untuk mereka. Sesungguhnya doa kamu itu (menjadi) ketenteraman jiwa bagi mereka. dan Allah Maha mendengar lagi Maha Mengetahui (Q.S. At-Taubah [9]: 103).

Dalam ayat tersebut jelas bahwa perintah Allah s.w.t langsung ditujukan kepada Nabi s.a.w. sebagai penguasa agar memungut harta shadaqah. Jumhur ulama semenjak dahulu sampai sekarang mengatakan bahwa yang dimaksud harta shadaqah dalam ayat tersebut adalah harta zakat (Al-Qaradhawi, II: 734). Sehingga selain perintah itu ditujukan kepada Nabi s.a.w., juga kepada setiap orang yang mengurus urusan kaum muslimin sesudahnya.

Menurut Kamus Besar Bahasa Indonesia, berkah adalah karunia Tuhan yang mendatangkan kebaikan bagi kehidupan manusia (Pusat Bahasa Departemen Pendidikan Nasional, 2002: 141). Sedang dalam buku Ensiklopedi Nasional Indonesia, kata "berkah" tidak ditemukan. Sebagai gantinya, digunakan istilah "berkat". Maknanya ada beberapa pengertian, yaitu: 1) "berkat" dalam pengertian adat, yaitu makanan yang dibawa pulang oleh orang yang telah menghadiri suatu kenduri, selamatan atau upacara keagamaan lainnya (Setiawan, 1988: 315); 2) doa restu yang diberikan para pemuka upacara pada berbagai upacara, termasuk upacara keagamaan. Misalnya pada upacara perkawinan agama Kristen Katolik, seorang pastor memberi berkat kepada pasangan pengantin di gereja. Meskipun para penganut agama Islam dan Budha memiliki kebiasaan memberikan doa restu serupa, namun mereka tidak menggunakan istilah "berkat" (Setiawan, 1988: 315-316). Buku Ensiklopedi Indonesia menyatakan secara lebih tegas lagi tentang keterkaitan "berkat" dengan ajaran Kristen Katolik. 
ljtihad: Jurnal Wacana Hukum Islam dan Kemanusiaan, Volume 17, No. 2, Desember 2017: 217-240

Berkat, dalam buku tersebut, merupakan permohonan iman kepada Tuhan untuk mendapatkan perlindungan Tuhan atau kemurahan-Nya atau kurnia-Nya bagi orang atau sesuatu barang, dengan menggunakan tanda salib. Biasanya disertai ucapan doa (Shadily, t.t.: 453).

Dalam buku Ensiklopedi Akidah Islam, istilah yang dipergunakan adalah "berkah", bukan "berkat". Keberkahan dimaknai sebagai karunia Tuhan yang terdapat pada diri seseorang atau pada benda tertentu. Seseorang yang memperoleh keberkahan akan memperoleh ketenangan hidup, seperti keberkahan rezeki dan keberkahan usia. Keberkahan juga dapat terjadi pada benda, berupa khasiat yang diperoleh dari benda itu. Misalnya air zamzam diyakini mempunyai berkah sebagai obat dari segala penyakit (Harahap, 2003: 75). Demikianlah keberkahan sebagaimana di atas, mengandung arti ketenangan, kemudahan, kemanfaatan penuh dan obat.

Quraish Shihab, menyebutkan bahwa barakah berarti kebajikan yang melimpah dan beraneka ragam serta bersinambung. Kolam dinamai birkah, karena air yang ditampung dalam kolam itu menetap mantap di dalamnya tidak tercecer kemana-mana. Keberkahan Ilahi datang dari arah yang seringkali tidak diduga atau dirasakan secara material dan tidak pula dapat dibatasi atau bahkan diukur. Dari sini segala penambahan yang tidak terukur oleh indera dinamai berkah (Shihab, 2001: 189).

Menurut Abul Hamdi, Allah s.w.t. membedakan kadar berbagai anugerah yang Ia berikan kepada masing-masing hamba-Nya, yang berupa harta, rezeki, akal, pemahaman dan lainnya, agar mereka saling bekerjasama dalam menjalankan roda kehidupan ini, sebagaimana dalam QS. 43: 32 (Hamdi, 2006: 3-4). Akan tetapi nilai keberkahan yang ada dalam semua jenis anugerah yang Ia berikan kepada manusia hanya terbatas kepada seorang muslim yang beriman dan bertakwa, sebagaimana disebutkan dalam QS 7: 96. "Laknat" adalah kebalikan dari "Berkah". Laknat ini Ia berikan kepada orang-orang yang berbuat maksiat, dosa dan orang-orang kafir, sebagaimana dalam QS 2: 159.

Abul Hamdi melanjutkan, bahwa ada 15 sebab dicabutnya berkah, yang menyebabkan seorang muslim dilaknat oleh Allah s.w.t., di antaranya adalah tidak bertakwa, tidak ikhlas dalam bekerja dan tidak menyebut basmalah (Hamdi, 2006: 9-109). Dari uraian Abul Hamdi tersebut, dapat disimpulkan bahwa berkah hanya terjadi pada seorang muslim yang beriman dan bertakwa. 
Haqiqi Alif menyebutkan keberkahan (barakah) itu sebagai ruh kehidupan. Menurut Alif, hidup di dunia, jika salah memilih jalan, akan jauh dari petunjuk Allah, jauh dari keberkahan dan dapat membuat sesak nafas, sehingga mudah putus asa, bingung, gelisah dan tidak dapat menikmati indahnya karunia Allah (Alif, 2007: 3). Berkah menurut Haqiqi Alif adalah ruh kehidupan dan sesuatu yang tidak dapat dipisahkan dalam kehidupan seorang muslim. Tanpa keberkahan hidup menjadi gersang. Menurut Haqiqi Alif, berkah mengandung makna dapat menikmati keberuntungan dari hasil jerih payahnya, merasakan ketenangan, kedamaian dan kebahagiaan.

Yuyu Wahyudin menyebutkan tentang harta sebagai amanah dan anugerah, jangan sampai menimbulkan fitnah (Wahyudin, 2008: 9-13). Watak manusia memang tidak akan merasa puas dengan harta seberapapun jumlahnya, sehingga motivasi untuk mencari harta dengan sungguh-sungguh itu tidak dikekang dalam ajaran Islam, tetapi justru diperintahkan (Wahyudin, 2008: 14-17). Namun perintah itu kemudian diiringi dengan anjuran tentang kedermawanan, dengan slogan tangan di atas lebih mulia ketimbang tangan di bawah (Wahyudin, 2008: 2023). Yuyu Wahyudin juga menjelaskan tentang anak yang merupakan anugerah dari Allah s.w.t., sebagai penerus perjuang orang tua. Anak adalah penyejuk mata bagi orang tua. Setiap orang tua menghendaki agar anaknya menjadi saleh, mampu beribadah dengan benar dan berakhlak terpuji, sehingga diperlukan sarana-sarana yang mendukung hal itu (Wahyudin, 2008: 118127). Dengan pendidikan yang baik dan benar, anak akan berbakti kepada kedua orang tua dan tidak terjerumus ke dalam budaya seks bebas (Wahyudin, 2008: 139-140, 148). Dari uraian di atas, Yuyu Wahyudin menyimpulkan keberkahan sebagai kebaikan dan kemanfaatan yang banyak, melalui sifat kedermawanan dan kesalehan. Dua sifat yang tidak asing di kalangan masyarakat muslim, dan menjadi idaman mereka dalam kehidupan sehari-hari.

Ahmad Gozali mengatakan bahwa keberkahan dapat diartikan sebagai kebaikan yang bertambah. Keberkahan adalah aspek keuntungan non-ekonomis dari suatu investasi. Salah satu bentuk dari keberkahan dalam berinvestasi ini adalah ketenangan dan kepuasan batin. Tenang karena investasinya dilakukan secara halal. Puas karena dapat memberikan kontribusi bagi pembangunan masyarakat (Gozali, 2004: 21, 26).

Menurut Arifin, berkah (barakah) tidak boleh dipahami dalam wujud yang nyata atau riil, yaitu jumlah harta yang senantiasa bertambah dan berlipat ganda. Kebaikan dan 
ljtihad: Jurnal Wacana Hukum Islam dan Kemanusiaan, Volume 17, No. 2, Desember 2017: 217-240

perkembangan harta, dapat saja terwujud dengan berlipat gandanya kegunaan harta tersebut, walaupun jumlahnya tidak bertambah banyak atau tidak berlipat ganda. Misalnya seseorang memiliki sedikit harta benda, namun karena harta tersebut penuh berkah, ia terhindar dari berbagai mara bahaya, penyakit dan tenteram hidupnya (Gozali, 2004: 7-8).

Abu Hudzaifah Ibrahim bin Muhammad memahami berkah (barakah) lebih rinci lagi. Menurut Ibrahim, Islam menciptakan ikatan dan hubungan yang memperjelas keterkaitan antara nilai spiritual dan nilai material. Di antara hal yang dapat menciptakan keseimbangan itu adalah ibadah dengan berbagai macamnya, serta apa saja yang dipandang perlu untuk memperkaya sisi kejiwaan dan kehidupan seorang muslim. Seperti shalat misalnya, dapat menyeimbangkan sisi kejiwaan yang tergambar dalam tabiat diri manusia, yang secara fitrah condong kepada peribadahan. Sisi kejiwaan ini seimbang dengan sisi materi yang tergambar dalam masyarakat yang tergambar dalam masyarakat yang menegakkan shalat berjamaah. Sisi materi tersebut adalah bahwa shalat berjamaah dapat mewujudkan sikap saling menolong, bersaudara, merasa sama sebagai hamba Allah dan beramar ma'ruf nahi munkar. Sedangkan posisi berkah dalam hal ini, bagaikan mata rantai yang menghubungkan keseimbangan yang besar tersebut. Dengan berkah, seorang muslim dapat menghubungkan keseimbangan tersebut, sehingga terwujudlah kenyamanan dan kebahagiaan di dunia dan akhirat. Hal itu dikarenakan berkah merupakan salah satu indikasi keridhaan sang Pencipta terhadap hambaNya yang melaksanakan perintah-perintah-Nya dan menjauhi larangan-larangan-Nya (Ibrahim, 2009: 11-12).

Menurut Ibrahim, berkah dapat berupa dua macam, yaitu berkah yang dapat dilihat dengan jelas dan berkah yang tidak dapat diindera. Adapun berkah yang dapat dilihat dengan jelas, adakalanya keberkahan tersebut terjadi secara wajar, adakalanya terjadi di luar kewajaran. Berkah yang terjadi secara wajar dapat dilihat melalui bertambahnya rezeki, perdagangan, usaha yang ditekuni seorang mukmin dan sebagainya. Adapun berkah yang terjadi di luar kewajaran, sebagaimana dijelaskan dalam hadis yang menceritakan tentang tangan Nabi s.a.w. yang dapat melakukan mukjizat yang diberkahi, seperti dapat memperbanyak makanan dan minuman yang pada mulanya hanya sedikit. Selain itu, ada pula berkah yang tidak dapat diindera. Akan tetapi seorang mukmin dapat merasakan pengaruhnya pada diri dan perasaannya. Maka iapun dapat merasakan ketenangan dan merasakan bahwa Allah meridhai 
dan menerima amalnya (Ibrahim, 2009: 13).

Untuk mengenali harta berkah ini, menurut Didin Hafidhuddin, dapat dilihat dari tiga aspek, yakni: (1) harta tersebut semakin mendekatkan (taqarrub) pemiliknya kepada Allah, (2) harta tersebut membawa manfaat bagi manusia lain, seperti untuk kepentingan sedekah, (3) harta yang diberikan Allah s.w.t. kepada seorang muslim, yang kemudian membuat dirinya merasa berkecukupan dengan harta tersebut (Hafidhuddin, 2007: 51-54). Didin Hafidhuddin dalam hal ini terinspirasi oleh Palgunadi T. Setyawan yang mengatakan bahwa harta yang baik itu dilihat dari sisi penggunaannya yang baik pula. Harta tersebut, menurut Setyawan, adalah harta yang mendekatkan pemiliknya kepada Allah, harta yang bermanfaat bagi orang lain dan harta yang pemiliknya merasa cukup (Setyawan, 2004: 91-95). Meskipun menurut Hafidhuddin indikasi harta berkah ini adalah selalu bertambah, tetapi harta tersebut tidak selalu harus banyak, namun selalu ada ketika dibutuhkan. Harta yang berkah meskipun sedikit, mampu menghidupi dan mencukupi apa saja yang dibutuhkannya. Terkadang, ada seseorang yang memiliki harta banyak, tetapi kemudian dirampok, atau sakit berkepanjangan (Hafidhuddin, 2007: 50-57).

Menurut AN. Ubaedy, menyuburkan sedekah ialah menciptakan perkembangan dari harta yang dimilikinya atau melipatgandakan berkah yang didapatkannya. Jika kita telah menunaikan sedekah, tetapi ternyata harta kekayaan kita tidak bertambah, bukan berarti sedekah kita gagal (tidak bekerja). Selama kita telah mengikhlaskan hati dalam bersedekah, maka penambahan itu harus kita imani sebagai kenyataan yang pasti terjadi. Hanya saja mungkin bentuknya penambahan fisik atau penambahan keberkahan (Ubaedy, 2009: 16-17).

Bahkan keberkahan hidup juga akan diraih oleh seseorang yang berbakti kepada orang tuanya. Banyak orang yang mengalami peristiwa-peristiwa tertentu atau berhasil melewati suatu ujian sebagai berkah dari berbakti kepada orang tua (Hamida, 2009: 126).

Dari uraian tentang berkah yang dilakukan peneliti, dapat disimpulkan bahwa berkah buat seorang muslim merupakan living value yang tidak ternilai. Berkah adalah kebajikan yang melimpah, beraneka ragam dan tidak dapat dibatasi, yang berbentuk fisik; seperti pertambahan harta, ketercukupan kebutuhan meskipun tidak bertambah atau bertambah sedikit hartanya, terhindar dari penyakit dan terhindar dari marabahaya, selain itu juga berbentuk nonfisik; seperti ketenangan, ketenteraman, kedamaian, kebahagiaan, kepuasan batin dan perasaan 
ljthad: Jurnal Wacana Hukum Islam dan Kemanusiaan, Volume 17, No. 2, Desember 2017: 217-240

bahwa Allah meridhai dan menerima amalnya; dan ada pula yang bersifat umum (fisik maupun nonfisik), seperti menikmati harta dan memperoleh kemudahan dari Allah (dalam setiap langkahnya), yang semua itu merupakan akibat dari keimanan dan ketakwaan seorang muslim kepada Allah s.w.t.

Adapun persentase keberkahan yang dirasakan muzaki, 98\% muzaki menyatakan bahwa mereka merasakan adanya keberkahan dalam berzakat dan keberkahan yang paling tinggi menurut mereka adalah ketenangan batin. Akan tetapi ketika persentase tinggi tersebut dikaitkan dengan kecenderungan pilihan berzakat ke lembaga zakat, maka hasilnya tidak berkorelasi.

\section{Keberkahan berzakat yang dirasakan muzaki}

Para responden muzaki menguraikan jenis keberkahan yang pernah mereka alami meliputi ketenangan batin, kemudahan urusan, perasaan tentang keridhaan Allah, efektifitas harta, dan terhindar dari hal-hal yang membahayakan.

\section{Ketenangan batin}

Tingginya nilai indikator ketenangan batin, telah sesuai dengan hasil wawancara dengan para responden muzaki maupun pengelola lembaga zakat. Para informan wawancara juga menguraikan hal yang sama, ketika mereka memberikan zakat kepada lembaga zakat. Karenanya, apabila indikator ketenangan batin menjadi indikator teratas yang dirasakan muzaki, itu merupakan sesuatu yang sangat wajar. Indikator ini dinyatakan dan dirasakan secara langsung oleh 3 (tiga) orang muzaki (Helmi, dkk, 24-26/2/2014). Ada 15 informan dari para pengelola zakat, yang menyatakan bahwa banyak responden yang menyatakan diri mereka merasakan ketenangan dengan berzakat ke lembaga zakat (Hidayat dkk, 17-20/2/2014).

Sebagian dari mereka ada yang menguraikan, bahwa ketenangan itu merupakan aspek nonfisik. Bagi muzaki, setelah mereka membayarkan zakatnya ke lembaga zakat, maka kemudian akan merasa plong (lega). Demikian penuturan Mishbahrudin (19/2/2014). Hal itu dikarenakan kewajiban mereka telah gugur, sebagaimana yang dijelaskan oleh Zuhron (18/2/2014). Bahkan Maryo menjelaskan, bahwa di antara indikasi kepuasan batin dan ketenangan itu adalah ketika amil LAZ datang, mereka telah menghitung sendiri zakatnya (Maryo, 19/2/2014). 
Tingginya nilai ketenangan batin dapat dijelaskan dengan realitas saat ini, ketika kasuskasus utama gangguan jiwa seperti skizofrenia, memiliki angka prevalensi sekitar 1\% populasi global atau sekitar 5\% populasi di Indonesia (http://www.news-medical.net/health/Schizophrenia-\%28Indonesian\%29.aspx, 6/8/2012). Sedangkan depresi dan kecemasan memiliki prevalensi sekitar 10-15\% dari populasi global. Bahkan pada tahun 2020 nanti, WHO memperkirakan gangguan depresi menjadi beban penyakit nomor 2 setelah gangguan jantung dan pembuluh darah (Andri, 27/6/2011).

Adanya fenomena penyakit kejiwaan tersebut, semakin memperkuat perasaan berkah dalam bentuk ketenangan batin yang dialami oleh muzaki. Itulah alasan mengapa Rasulullah s.a.w. diperintahkan oleh Allah ta'ala untuk mendoakan muzaki setelah mereka berzakat, sebagaimana dijelaskan Allah ta'ala dalam QS At-Taubah: 103.

\section{Kemudahan urusan}

Bagi muzaki yang pada umumnya menganggap kemudahan urusan termasuk indikator pada urutan utama, hal ini sesuai dengan banyak ayat yang menyatakan secara langsung tentang janji Allah ta'ala kepada orang-orang bertakwa, bahwa mereka akan diberikan kemudahan, sebagaimana disebutkan dalam QS. 65: 4-5. Bahkan Rasulullah s.a.w. sendiri secara langsung diyakinkan oleh Allah ta'ala, pada saat berperang melawan orang-orang musyrik, bahwa beserta kesulitan itu ada kemudahan, sebagaimana disebut dalam QS. 94: 5-6. Salah satu keberkahan tersebut adalah kemudahan urusan. Sebagai contoh kasus yang ada adalah yang terjadi pada Antok (22/4/2014), seorang pemilik rental mobil di Yogyakarta, yang berharap secara terang-terangan agar usaha rentalnya dijadikan oleh Allah ta'ala, dapat berjalan lancar, setelah ia berzakat ke Rumah Zakat. Tentu harapan seperti ini bukan harapan semu, namun merupakan harapan yang memang sebagiannya telah ia rasakan ataupun dirasakan oleh orang-orang sekitar Antok, berdasarkan pengakuan mereka di hadapan Antok.

Hal yang senada juga dialami oleh Supomo ketika menghadapi sekian banyak muzaki. Menurut Supomo (19/2/2014), ada kasus muzaki yang berzakat di lembaga zakat yang ia kelola, menceritakan bahwa ia sudah sekian tahun tidak punya putra, kemudian dimudahkan Allah mempunyai anak, setelah berzakat. Ada pula, kemudahan untuk seseorang yang kondisinya susah, tetapi karena ia tetap memberikan zakat kepada orang lain, akhirnya menjadi mudah. 
ljtihad: Jurnal Wacana Hukum Islam dan Kemanusiaan, Volume 17, No. 2, Desember 2017: 217-240

Dari kisah-kisah nyata di atas, tampak bahwa pertolongan Allah ta'ala kepada orang yang beriman dan bertakwa, benar-benar nyata. Dari tiga bentuk pertolongan Allah, semuanya nyata. Mulai dari menunjukkan jalan keluar setiap masalah yang menimpanya, memberi rezeki dari pintu-pintu yang tidak terduga, dan menjadikan urusannya selalu mudah diatasi. Ada satu pertolongan yang terakhir, adalah terjadi di akhirat kelak, yaitu penghapusan dosa dan pelipatgandaan pahala.

\section{Perasaan tentang keridhaan Allah}

Perasaan tentang keridhaan Allah terdiri dari tiga indikator, yaitu: perasaan bahwa Allah ta'ala meridhai, perasaan bahwa Allah ta'ala menerima amal dan terkabulnya doa. Tiga indikator tersebut menunjukkan bahwa Allah ta'ala telah meridhai perbuatan para muzaki. Namun demikian, tidak mudah untuk mengungkapkan indikator-indikator ini, khususnya dua item yang pertama, yakni perasaan bahwa Allah ta'ala meridhai dan perasaan bahwa Allah ta'ala menerima amal. Hal itu dikarenakan indikator ini terkait dengan amalan hati yang bagi banyak orang, tidak mudah melukiskannya.

Sebagian dari pengelola zakat ada yang menguraikan tentang item perasaan bahwa Allah ta'ala menerima amal seorang muzaki. Sepintas lalu jika salah dalam memahami item ini, dapat menimbulkan persepsi negatif, yaitu kesombongan. Artinya seseorang yang beramal tidak semestinya merasa bahwa amalnya telah diterima oleh Allah ta'ala. Jika ia merasa demikian, maka berarti sombong dan justru tidak baik.

Maksud dari item perasaan bahwa Allah ta'ala menerima amal dan meridhai muzaki, adalah keyakinan bahwa yang mereka lakukan telah sesuai dengan yang dikehendaki Allah ta'ala, disertai keikhlasan yang memadai, sehingga berefek pada perasaan bahwa Allah ta'ala meridhai dan menerima amal. Menurut Mukhlis, Ketua Prozis Ibnu Abbas Klaten, berkah yang paling besar dirasakan muzaki, justru bersifat nonfisik, yaitu keikhlasan, tidak mau diketahui, hanya ingin membantu begitu saja. Berkah inilah yang berefek pada perasaan muzaki bahwa Allah menerima amal, karena lebih banyak dari muzaki-muzaki ini, tidak mau berkomunikasi langsung dengan lembaga zakat dan lebih banyak berinteraksi dengan Ustadz Mu’in, melalui jamaah pengajian Maghfirah, Jakarta (Mukhlis, 19/2/2014). 
Prozis yang dikelola oleh Mukhlis, tergolong unik, karena memiliki tokoh sentral yang banyak menjadi pintu masuk zakat-zakat masyarakat. Oleh karenanya, pengalaman yang ditemui oleh Mukhlis, tidak banyak ditemui pada lembaga-lembaga zakat lainnya. Sehingga keberkahan yang dirasakan menonjol oleh muzaki pun juga berbeda dengan lembaga-lembaga zakat lainnya.

Apa yang dilakukan oleh para muzaki di Prozis, sesungguhnya merupakan aplikasi dari derajat tinggi seorang hamba di hadapan Allah, yang pernah dilukiskan oleh Allah ta'ala dalam Al-Qur'an, sebagai berikut:

Sesungguhnya kami memberi kalian makan hanya mengharap wajah Allah, kami tidak menghendaki dari kalian, balasan dan tidak pula menghendaki ucapan terimakasih (Q.S. Al-Insan [76]: 9)

Berbeda halnya dengan jenis keberkahan dengan indikator terkabulnya doa. Indikator terkabulnya doa ini, pernah disebutkan oleh al-Baghdadi (al-Baghdadi, tt, IX: 10-11). Ada tiga versi pemahaman yang ada di kalangan para muzaki dalam hal ini, yaitu: a) Sebagian dari mereka ada yang memahami bahwa terkabulnya doa tersebut dari pihak muzaki secara langsung; b) Ada lagi muzaki lain yang memahami bahwa terkabulnya doa itu melalui amil zakat; c) Sedangkan yang lain memahami bahwa terkabulnya doa tersebut melalui mustahik yang diberi zakat, sehingga muzaki merasa penting untuk dipertemukan dengan mustahik zakat.

Bagi yang memahami bahwa terkabulnya doa dari pihak muzaki langsung, itulah yang dialami oleh mayoritas muzaki, sebagaimana dinyatakan oleh banyak muzaki, berdasarkan penuturan para pengelola zakat (Hidayat, dkk, 17-20/2/2014). Menurut Yasmidi, ada salah seorang muzaki di lembaga zakatnya yang bercerita, bahwa ia telah berzakat dalam bentuk memberikan beras 25 kilogram sebanyak dua kali, kepada lembaga zakat. Lalu setelah itu ia berdoa kepada Allah ta'ala agar keinginannya membeli ruko terkabulkan, dan tidak berapa lama setelah itu benar-benar terkabulkan (Yasmidi, 20/2/2014).

Sebagian muzaki ada yang memahami bahwa terkabulnya doa itu melalui amil zakat, ketika muzaki berzakat ke lembaga zakat. Oleh karena itu, tidak segan-segan bagi mereka, untuk secara terang-terangan meminta didoakan oleh pengelola zakat, sebagaimana yang dituturkan oleh Ucu Sutrisno (19/2/2014). 
ljtihad: Jurnal Wacana Hukum Islam dan Kemanusiaan, Volume 17, No. 2, Desember 2017: 217-240

Sebagian muzaki lainnya ada yang memahami bahwa terkabulnya doa itu dari pihak mustahik langsung. Sehingga ada sebuah lembaga zakat yang diminta oleh muzakinya untuk dipertemukan dengan mustahik secara langsung. Itulah yang dialami oleh Mukhlis, Manajer Prozis Klaten. Berdasarkan penuturan Mukhlis, ada seorang ibu yang mencari mustahik melalui Prozis, tetapi setelah bertemu, ia berikan langsung zakatnya pada anak tersebut. Ketika ibu itu sakit, langsung anak tersebut diminta mendoakan. Pernah pula ibu tadi meminta anak asuhan tadi supaya mendoakan agar tanah pabriknya segera terjual. Lalu tidak berapa lama setelah itu terkabul dan sebagai imbalannya, lembaga zakat dikirimi dana sejumlah Rp. 14.000.000,00, sebagai sedekah. Mungkin itulah yang menjadi harapan muzaki, sehingga memiliki hubungan dekat dengan mustahik.

\section{Efektifitas harta}

Di antara indikator keberkahan selanjutnya yang amat dirasakan oleh muzaki, adalah efektifitas harta. Maksud dari efektifitas harta adalah bahwa harta tersebut bertambah, dan atau tercukupinya kebutuhan, dan atau menikmati harta miliknya sendiri.

Menurut pengalaman Itoh (18/2/2014), para muzaki banyak yang merasakan keberkahan dalam bentuk tercukupinya kebutuhan. Itoh menyebutnya dengan istilah "pas butuhpas eneng". Maksudnya adalah saat dibutuhkan, saat itu pula ada. Hal senada juga diungkapkan oleh 4 pengelola zakat selain Itoh, bahwa banyak muzaki yang merasakan adanya keberkahan, dalam bentuk pertambahan harta dan tercukupinya kebutuhan (Mursito, dkk, 18-20/2/ 2014).

Pengalaman Itoh menegaskan tepatnya hadis Rasul s.a.w., bahwa memang ada sekelompok orang yang diberikan rezeki oleh Allah s.w.t., namun secukupnya sesuai dengan kebutuhan. Berikut hadis Rasul s.a.w. yang menunjukkan hal tersebut:

Dari Abdullah bin 'Amr r.a., bahwasanya Rasulullah s.a.w. bersabda: Sungguh telah beruntung orang yang berislam (tunduk/patuh) dan ia dianugerahi rezeki secukupnya serta Allah menetapkan dalam dirinya sifat qana'ah (menerima apa adanya), terhadap apa yang Ia anugerahkan padanya (H.R. Hakim).

Orang yang diberi rezeki secukupnya biasanya tidak terlihat sebagai orang yang mampu atau berada di kalangan masyarakat. Namun demikian, kebutuhan sehari-hari yang bersifat 
rutin maupun insidentil, walaupun besar, tetapi tercukupi juga. Itulah namanya keberkahan, yang termanifestasikan melalui indikator tercukupinya kebutuhan. Dalam bahasa Quraish Shihab, keberkahan semacam ini merupakan keberkahan Ilahi yang datang dari arah yang seringkali tidak diduga atau dirasakan secara material dan tidak pula dapat dibatasi atau bahkan diukur (Shihab, 2001, IV: 189).

Di antara indikasi para muzaki berupaya untuk menikmati harta secukupnya saja, adalah adanya persepsi mereka bahwa faktor mereka berzakat ke lembaga zakat adalah karena ada harta orang lain dalam harta mereka. Hal itu diungkapkan oleh setidak-tidaknya 4 muzaki (Agus, dkk, 19-21/4/2014). Mereka beranggapan bahwa kewajiban 2,5\% itu memang harus dikeluarkan dari harta mereka. Bagi mereka, tidak banyak tidak masalah, asal mencukupi, daripada banyak tetapi membawa petaka, karena ada harta orang lain yang belum diberikan.

\section{Terhindar dari hal-hal yang membahayakan}

Keberkahan dapat pula dimaknai sebagai tertolaknya seseorang dari hal-hal yang membahayakan, baik itu berupa penyakit maupun marabahaya lainnya. Makna ini sejalan dengan hadis Rasulullah s.a.w. sebagai berikut:

Dari Jabir, berkata: seseorang yang berasal dari suatu kaum berkata: Wahai Rasulullah, tahukah engkau (balasan) jika seseorang telah menunaikan zakat mal-nya? Lalu Rasulullah menjawab, "Barang siapa yang telah menunaikan zakat mal-nya, maka sungguh telah sirna kejahatan harta darinya.” (HR. Thabrani)

Jadi maksud dari kejahatan harta itu bukan hartanya menjadi jahat, tetapi hartanya menjadi tidak aman dari bahaya-bahaya, seperti pencurian, hilang, rusak yang belum saatnya, dan sebagainya. Bagi orang yang telah berzakat, kasus seperti itu menjadi minim bahkan tertolak sama sekali, karena adanya keberkahan dalam bentuk terhindar dari hal-hal yang membahayakan. Ibnu Qayyim al-Jauziyyah menyebutkan bahwa harta tersebut telah terpagari melalui ibadah zakat, sehingga dengan sendirinya dapat menjaga keamanan muzaki (Ibnu Qayyim Al-Jauziyyah, 1998:, 262).

Fungsi zakat yang dapat memunculkan keberkahan dalam bentuk terhindar dari marabahaya, pernah dinyatakan oleh Yanur Wibowo, Manajer LAZ Al-Ihsan Jateng Cabang Magelang (18/02/2014). Berdasarkan interaksi yang dilakukan Wibowo dengan para muzaki, 
ljthad: Jurnal Wacana Hukum Islam dan Kemanusiaan, Volume 17, No. 2, Desember 2017: 217-240

ada suatu kenyataan yang dialami oleh masyarakat terkait dengan terhindarnya mereka dari letusan gunung Merapi. Menurut Yanur, muzaki yang ahli zakat dan sedekah, itu hasil pertaniannya (salak dan lainnya) paling aman. Jika rusak, maka itu hanya sedikit saja.

Bahkan pengalaman lebih menarik lagi adalah terjadi pada sebagian muzaki yang dikelola oleh LAZIS UNS Surakarta. Catur Wibowo, Manajer LAZIS UNS (18/02/2014), menyebutkan bahwa ada sebagian muzaki yang berdasarkan perkiraan, seharusnya ia sudah mengalami kecelakaan mobil atau motor, namun ternyata tidak jadi. Tentu ini merupakan sebagian dari bentuk keberkahan, yakni terhindar dari marabahaya. Sebenarnya kasus seperti ini adalah bentuk pengamalan dari sebuah hadis Rasulullah s.a.w. sebagai berikut (At-Thabrani, 1995: 40):

Dari Abdullah bin Buraidah, dari ayahnya, berkata, Rasulullah s.a.w. bersabda: "Tidaklah suatu kaum mencegah (dari kewajiban membayar) zakat kecuali Allah menguji mereka dengan paceklik (HR. Thabrani)."

Hadis di atas memberikan pemahaman bahwa seandainya satu kaum tidak mengeluarkan zakatnya, akan mengundang musibah yang diturunkan oleh Allah ta'ala pada mereka. Hal yang sama juga terjadi pada individu, seandainya telah berkewajiban zakat namun tidak mengeluarkannya, sehingga hartanya menjadi tidak berkah, tidak aman dari penyakit dan marabahaya lainnya.

\section{Penutup}

Lembaga zakat perlu memperhatikan hal-hal seputar para muzaki, yang dapat memotivasi mereka untuk mengoptimalkan dana mereka ke lembaga zakat. Dengan mengetahui seputar keberkahan yang dirasakan oleh muzaki setelah mereka mengeluarkan zakat, dapat semakin menguatkan para muzaki untuk terus bekerjasama dan mempercayakan harta zakat mereka kepada lembaga zakat. Bahkan, bagi yang belum berzakat ke lembaga zakat, informasi seputar perasaan berkah dalam item-item yang disebutkan dalam penelitian ini, perlu juga diketahui oleh lembaga-lembaga zakat, untuk meyakinkan para muzaki agar mereka semakin memberikan dana zakat mereka melalui lembaga-lembaga zakat yang terdekat.

Ketenangan batin, kemudahan urusan, perasaan tentang keridhaan Allah, efektifitas harta dan terhidar dari hal-hal yang membahayakan, merupakan indikator-indikator keberkahan 
yang sangat dirasakan oleh para muzaki. Namun bukan berarti indikator-indikator keberkahan berzakat hanya 5 indikator itu saja. Masih diperlukan penelitian-penelitian lebih lanjut, seputar program-program lembaga zakat untuk mengaktualisasikan indikator-indikator tersebut dalam bentuk aksi riil, yang menghubungkan antara lembaga-lembaga zakat dan para muzaki.

\section{Daftar pustaka}

Abdurrasul, Ali. Al-Mabadi' al-Iqtishadiyyah fi al-Islam wa al-bina' al-iqtishadi li ad-Daulah alIslamiyyah, Kairo: Daru al-Fikr al-'Arabi, 1980.

Al-Asqalani, Ibnu Hajar. Fathu al-Bary Syarh Shabih al-Bukhari, Beirut: Dar al-Fikr, III, tt.

Al-Baghdadi, Abu al-Fadhl Syihabu ad-Din Mahmud al-Alusi. Rubu al-Ma'ani fi Tafsiri alQur'ani al-'azhimi wa as-Sab'i al-Masani, Beirut: Ihya-u at-Turats al-'Arabi, IX, tt.

Al-Baidhawi, Nashiru ad-Din Abu al-Khair Abdullah, bin 'Umar bin Muhammad. Anwar at-Tanzil Wa Asrar at-Ta'wil, Istanbul: Maktabah al-Haqiqah, I, 1998.

Al-Jauziyyah, Ibnu Qayyim. Zadu al-Ma'ad fi Hadyi Khairi al-'Tbad, Kairo: Daru al-Qalam li at-Turats, I, 1998.

Al-Qaradhawi, Yusuf. Fiqhu az-Zakah, Beirut: Mu'assasat ar-Risalah, terj. Salman Harun dkk, dengan judul Hukum Zakat, cet. ke-6, terbitan PT. Pustaka Litera AntarNusa, Jakarta: 1973.

Ali, Mohammad Daud. Sistem Ekonomi Islam Zakat dan Wakaf, Jakarta: Penerbit UI, cet. ke$1,1988$.

Alif, M. Haqiqi. Salah Kaprah Ngalap Berkah, cet. ke-1, Jombang, Lintas Media, 2007.

Andri. "Mengapa Kita Butuh Psikiater" dalam http:/ / kesehatan.kompasiana.com/medis/ 2011/ 06/27/mengapa-kita-butub-psikiater/, tanggal 27 Juni 2011, diakses tanggal 2 Agustus 2012.

An-Naisaburi, Abu al-Hasan 'Ali bin Ahmad al-Wahidi [w. 468 H]. Al-Wasith fi Tafsir alQur'ani al-Majid. Beirut: Daru al-Kutub al-'Ilmiyyah, I, 1994 .

At-Thabrani, Hafizh Abi al-Qasim Sulaiman bin Ahmad. Al-Mu'jam al-Ausath, Kairo: Daru al-Haramain, 1995.

Baldwin, J. Norman. "Public versus Private Employees: Debunking Stereotypes" in Review of Public Personnel Administration, 1991, 11 (1/2), pp. 1-27, 1991.

Baznas dan Fakultas Ekonomi dan Manajemen IPB. "Estimasi Potensi Zakat Nasional", dalam http:/ / sabili.co.id/lentera/ estimasi-potensi-zakat-nasional/, tanggal 22/8/2011, diakses tanggal 8 Agustus 2012. 
ljthad: Jurnal Wacana Hukum Islam dan Kemanusiaan, Volume 17, No. 2, Desember 2017: 217-240

Bellante, Don, and Albert N. Link. "Are Public Sector Workers More Risk Averse than Private Sector Workers?" in Industrial and Labor Relations Review, 34 (3), p. 408-412, 1981.

Departemen Pendidikan dan Kebudayaan. Kamus Besar Bahasa Indonesia, Jakarta: Balai Pustaka, 2002, Edisi ketiga.

Geertz, Clifford. "Religion as a Culture System" in Clifford Geertz, Interpretation of Cultures, Selected Essays, New York: Basic Books, p. 90, 1973.

Gozali, Ahmad Halal, Berkah, Bertambah Mengenal dan Memilih Produk Investasi Syariah, cet. ke-2, Jakarta: Penerbit PT. Elex Media Komputindo, 2004.

Gomes, F.C. Manajemen Sumber Daya Manusia. Yogyakarta: Penerbit Andi Yogyakarta, 2003.

Greene, William H. Econometric Analysis. New Jersey: Upper Saddle River, Fifth Edition, pp. 773-774, 2002.

Hafidhuddin, Didin. Agar Harta Berkah dan Bertambah Gerakan Membudayakan Zakat Infak Sedekah dan Wakaf. Jakarta: Gema Insani, 2007.

Hamdi, Abul. 15 Sebab Dicabutnya Berkah. cet. ke-2. Jakarta: Gema Insani, 2006.

Hamida MZ, Abu, Birru al-Walidain Super Berkah Buah Manis Berbakti Kepada Ibu-Bapak, cet. ke-1, Bandung: Pustaka Hidayah, 2009.

Harahap, Syahrin, dkk., Ensiklopedi Aqidah Islam, cet. ke-1, Jakarta: Prenada Media, 2003.

Hervina. "Implikasi Pembayaran Zakat Penghasilan terhadap Berkah dalam Berusaha, Studi

Kasus Pengusaha Kayu di Kota Samarinda, Kalimantan Timur", Tesis, Program Pascasarjana Universitas Islam Negeri, 2004.

Http://www.antara.co.id, diakses tanggal 12 September 2008.

Husserl, Edmund. Cartesian Meditation an Introduction to Phenomenology. The Hague: Martinus Nijhoff, p. 49.

Ibrahim bin Muhammad, Abu Hudzaifah. Rahasia Hidup Penuh Barokah 33 Sebab Datangnya Keberkahan di Dalam Rezeki dan Kebidupan. cet. ke-1. Solo: Qiblat Press, 2009.

Iqbal, Zamir and Abbas Mirakhor. An Introduction to Islamic Finance Theory and Practice, Singapore: John Wiley and Sons Pte Ltd, p. 42-43, 2007.

Kilpatrick, Franklin P., Cummings Milton C., and M. Kent Jennings. The Image of the Federal Service, Washington, DC: Brookings Institution, p. 23-24, 1964.

Pasiak, Taufik. Manajemen Kecerdasan: Memberdayakan IQ, EQ dan SQ untuk. Kesuksesan Hidup. Bandung: Penerbit Mizan, p. 123-124, 2007.

Rama, Ali. "Ekonomi Syariah dan Outlook 2011" dalam Republika, 2010, diakses tanggal $29 / 12 / 2010$. 
Rosadi, Idi. "Masyarakat dan Zakat: Respon Masyarakat terhadap Lembaga Ekonomi Islam (Studi Pengelolaan Zakat di Badan Amil Zakat Kec. Panjalu Kab. Ciamis Jawa Barat)”. Tesis. Program Pascasarjana Universitas Islam Indonesia, 2007.

Setiawan, Boenyamin. dkk. Ensiklopedi Nasional Indonesia. cet. ke-1. Jakarta: PT. Cipta Adi Pustaka, 1988, III.

Setyawan, Palgunadi T. Daun Berserakan Sebuah Renungan Hati. cet. ke-3. Jakarta: Gema Insani, 2004.

Shadily, Hassan. dkk. Ensiklopedi Indonesia. Jakarta: PT. Ichtiar Baru-Van Hoeve, t.t.

Shihab, M. Quraish. Tafsir Al-Mishbah, Jakarta: Lentera Hati, cet. ke-1, IV, p. 189, 2001.

Sugiyono. Statistika untuk Penelitian. Bandung: CV. Alfa Betha, 2009. p. 70-71.

Syah, Muhibbin. Psikologi Belajar. Jakarta: Logos.

Syafei, Erni Suhasti. "Faktor-faktor yang Mempengaruhi Pembayaran Zakat Masyarakat Prenggan-Kotagede Yogyakarta”. Tesis. Program Pascasarjana Universitas Islam Indonesia, 2003.

Tim Redaksi. "Baznas: Potensi Zakat Nasional Rp 217 Triliun” in bttp:/ / www.republika.co.id/ berita/ramadhan/kabar-ramadhan/11/08/19/lq6ibr-baznas-potensi-zakat-nasional-rp-217triliun, diakses tanggal 4 November 2013.

Tim Redaksi. "Potensi Zakat Indonesia Rp. 9 Triliun”, in http://www.antara.co.id, diakses tanggal 12 September 2008.

Ubaedy, AN. Hikmah Bersedekah Berkah dalam Kelapangan Hidup dengan Berbagi Kebaikan. Jakarta: Bee Media Indonesia, 2009.

Wahyudin, Yuyu. Agar Harta dan Anak menjadi Berkah. cet. ke-1. Jakarta Timur: Pustaka AlKautsar, 2008.

Wawancara dengan Agus, muzaki Yogyakarta, pada tanggal 21/04/2014, Rindi, muzaki yang berlatar belakang guru di Sleman pada tanggal 21/04/2014, Sukamto, muzaki Yogyakarta yang berprofesi pemilik toko kaca, pada tanggal 19/04/2014, dan Husein Fahrudi, muzaki berprofesi dosen di Yogyakarta, pada tanggal 19/04/2014.Wawancara dengan Antok di Yogyakarta, pada tanggal 22/4/2014. Wawancara dengan Irfan Helmi (24/02/2014), Yahya (25/02/2014) dan Upang Sofyan (26/02/2014).

Wawancara dengan Itoh (18/02/2014), Rafi (18/02/2014), Yanur Wibowo (18/02/2014), Tri mursito (18/02/2014), Zuhron (18/02/2014), Supomo (19/2/2014), Misbahrudin (19/2/2014), Bagas Laksono (19/2/2014), Susmono (19/2/2014), Maryo (19/2/ 2014), Yusuf (20/2/2014), Drajat (20/2/2014), Joko Adi Saputro (20/2/2014) dan Sakidi (20/2/2014). 
ljthad: Jurnal Wacana Hukum Islam dan Kemanusiaan, Volume 17, No. 2, Desember 2017: 217-240

Wawancara dengan Maryo, selaku Sekretaris LAZ MUH Salatiga, pada tanggal 19/02/ 2014.

Wawancara dengan Misbahrudin, selaku Kepala Staf Sekretariat BAZDA Yogyakarta, pada tanggal 19/2/2014. Wawancara dengan Samino (26/02/2014), Abdul Ghafur (01/ 03/2014), Adang Kuswaya (19/04/2014), Ifonilla Yeniati (19/04/2014), Bashori (19/ 04/2014), Supartinah (22/04/2014), Idi Joko Sudono (22/04/2014), Syaerozi (22/ 04/2014), Rahmat Hasan (22/04/2014), Mubasirun (22/04/2014), Juz'an (22/04/ 2014) dan Sulistiyorini (23/04/2014).

Wawancara dengan Mukhlis selaku Ketua Prozis Ibnu Abbas Klaten, tanggal 19/02/2014.

Wawancara dengan Supomo, selaku Manajer Solopeduli Surakarta, pada tanggal 19/02/ 2014.

Wawancara dengan Taufikurrahman, selaku Manajer RZIS UGM (18/02/2014).

Wawancara dengan Tri Mursito selaku Staf bagian Keuangan BAZ Kota Semarang (18/ 02/2014), Zuhron selaku Manajer LAZIS UMM (18/02/2014), Ucu Sutrisno selaku Pengelola RZI Kota Semarang (19/02/2014) dan Yusuf selaku Ketua lembaga zakat YASR Klaten (20/02/2014).

Wawancara dengan Ucu Sutrisno selaku Pengelola RZI Kota Semarang, pada tanggal 19/ $02 / 2014$.

Wawancara dengan Yasmidi selaku Pengelola Lembaga Zakat Jatisari, Kecamatan Mijen, Semarang, tanggal 20/02/2014. Wawancara dengan Zuhron, selaku Manajer LAZIS UMM Magelang, pada tanggal 18/02/2014.

Wawancara dengan 13 responden lelaki, yaitu pada tanggal 9 Agustus 2012 dengan Puyawahana dan Mubasirun, dan pada tanggal 12 Agustus 2012 dengan Sigit, Giyanto, Solikhun, Zamroni, Muhsin, Abdul Aziz, Ahmadi, Nasrodin, Rohib, Farkhani dan Eko Purnomo.

Wawancara dengan 13 para muzaki perempuan yang membayarkan zakatnya langsung ke mustahik langsung, yaitu Widayati, Win, Nafi'atul Birroh, Umi, Ismarmiyati, Lastri, Shol, Nurul, Ida, Syarifah, Aisyah, El Widuri, Peni Susapti dan ada satu responden lagi yang tidak berkenan menyebutkan nama, antara tanggal 10-12 Agustus 2012. 